\title{
THE SILENT POLITICS OF EDUCATIONAL DISADVANTAGE AND THE NATIONAL ANTI-POVERTY STRATEGY
}

\author{
Roland Tormey
}

\begin{abstract}
Educational disadvantage is an essentially contested, political concept. At the same time there is a "phoney consensus" (O’Sullivan, 1999) surrounding the issue, i.e., policy debates on the topic often fail to reflect this contestation. This lack of awareness of the political context to the debate is evident in relation to the targets and measures set for addressing educational disadvantage. While Lynch (1999) has pointed out the political undertones of 'comparative' targets and measures, the conservative political position inherent in the 'outputs-led' model has not properly been explored. Indeed, the apparently technical and value-free nature of targets and measures has enabled this conservative political perspective to become embedded in public educational policy without debate.
\end{abstract}

(post-print version

Published in Irish Educational Studies Volume 29, Issue 2, 2010, pp. 189-199

http://www.tandfonline.com/doi/full/10.1080/03323311003779076) 


\section{THE SILENT POLITICS OF EDUCATIONAL DISADVANTAGE AND THE NATIONAL ANTI-POVERTY STRATEGY}

The political "master" always finds himself vis-à-vis the trained official, in the position of a dilettante facing the expert. This holds whether the "master"... is the "people" equipped with the weapons of legislative initiative, referendum and the right to remove officials; or a parliament elected on a more aristocratic or more democratic basis... (Weber 1922/ 1978, 991).

\section{Introduction}

In this paper I am concerned with exploring the way in which technical expertise, which appears value-free but which is in fact inherently political, becomes a mechanism for stifling debate and denying a space for democratic contestation. I argue that, although the term educational disadvantage can be described (to use Gallie’s term) as an "essentially contested concept” (1955/6), it is typically presented in policy documents as if it is a term about which there is a consensus. In this consensual presentation, the question of setting targets for educational disadvantage policy becomes 'simply' a technical question that requires a technical answer. In this way, technical expertise plays a role in stifling debates and preventing democratic contestation. This has resulted in a politically conservative understanding of educational disadvantage becoming spirited into the practical processes of identifying who is, and who is not, 'educationally disadvantaged'.

Carr has argued in relation to curriculum (though the point might well be expanded to include educational debates more generally) that, "the general ideological perspectives underlying contending... views remain unarticulated and undisclosed and, therefore... make ideologically dominant educational views seem unproblematic and self-evidently true” (1998, 326). According to Sugrue and Gleeson it is necessary to bring to the 
surface what they refer to as these structured silences about educational policy reform in order to provide a "contrapuntal" reading of discourses on educational reforms (2004, 269). Just such a structured silence can be seen in relation to the measurement of educational disadvantage. In exploring this process, I have used the targets for educational disadvantage policy identified in the Irish National Anti-poverty Strategy (NAPS) in the late 1990s and early 2000s as a case study, although, as I will identify towards the end of this paper, the analysis presented here does have wider and more recent applications.

In this paper I will first look at attempts to define educational disadvantage and, making use of Gallie's notion of an essentially contested concept, I will argue that it is not in a single definition of educational disadvantage but in exploration of a multiplicity of understandings that we will find illumination. I then move on to look at the way in which different measures and targets for educational disadvantage policy are inherently political, though they may not be recognised as such. With reference to the NAPS, I will then show that this mis-recognition of the political nature of such targets led to a conservative understanding of educational disadvantage becoming operationalised in what was apparently intended to be a more politically liberal document. This decision continues to have an impact today, since contemporary policy targets are little more than re-heated versions of those set in the NAPS.

\section{Contested definitions of educational disadvantage}

Definition is often regarded as a crucial first step in academic debate. On the surface of 
it, this should be relatively unproblematic in the case of the term educational disadvantage, given that it is widely used in Ireland in Government policy documents (e.g. Ireland 1997; 2002), in academic writing (e.g. Kellaghan et al. 1995; Boldt and Devine 1998; Tormey 1999; Power and Tormey 2000; Kellghan 2001; Lyons 2002; Conway 2002; Weir and Archer 2005), in the language of teachers (INTO 1994) and in the work of the Government's educational disadvantage expert committee (Educational Disadvantage Committee 2004; 2005). The term is also used internationally, in the work of bodies like the OECD (1992), UNICEF (2002), the Joseph Rowntree Charitable Trust (2007) as well as in the work of academics (e.g., Cox 2000; James 2005). UNICEF note that educational disadvantage is a feature of all OECD countries (2002, 3) though in other countries (and sometimes in Ireland) other terms such as educational inclusion/ exclusion or educational equality/ inequality are sometimes used instead of educational disadvantage. Whether or not these terms are better at making clear the political positions which underpin their use is open to discussion (see Levitas 2005, for example).

In Ireland, the concept of educational disadvantage is so central to Irish educational policy that it is actually defined in law. Section 32, paragraph 9 of the Education Act 1998 identifies that the term educational disadvantage means "the impediments to education arising from social or economic disadvantage which prevent students from deriving appropriate benefit from education in schools”. However, this definition, like others used internationally, has been criticised for being broad and non-specific and for failing to identify what are the impediments in question (Kellaghan 2001). Based on his analysis of these weaknesses, Kellaghan has offered a different definition: 
A child may be regarded as at a disadvantage at school if because of factors in the child's environment conceptualised as economic, cultural and social capital, the competencies and dispositions which he/she brings to school differ from the competencies and dispositions which are valued in schools and which are required to facilitate adaptation to school and school learning (italics in original, Kellaghan 2001, 5).

Yet this definition is contestable too, for example, on the grounds that it locates the locus of disadvantaging in the 'factors in the child's environment' rather than in the political power which shapes what is 'valued in school' (see Bourdieu and Passeron 1977, for example). So, while there is some comfort in seeking to find an agreeable, clear and useful definition of the term educational disadvantage, the effort may be misplaced. As Gallie noted half a century ago, there are concepts for which it is fundamentally impossible to agree a definition because, while the concepts are shared across political or other interest groups, their meaning for each group is embedded in their own belief system (1955/6). He called these concepts 'essentially contested concepts' and identified that they included concepts like Democracy, Social Justice and Art. For Gallie, one corollary of accepting that such concepts were 'essentially contested' was that we can come to see in the existence of alternative understandings "permanent potential critical value to one's own use or interpretation of the concept in question” $(1955 / 6,193)$. Applying this logic to the term 'educational disadvantage' would suggest that demanding an agreed definition of the term (or worse, engaging in a "phoney consensus" [O'Sullivan 1999] in which we assume there is an agreed definition without ever clearly articulating it) may be of less value than engaging with the diversity of positions associated with the term and with the critical illumination which these positions offer to each other (see also O’Sullivan 2005, 319). 
Numerous writers have sought to map out the different political positions that can form the context of such a contestation. Baker (1998) and Lynch (1999), for example, have distinguished between basic, liberal and radical accounts of equality while in the UK Levitas (2005) has also presented a three-fold model in her account of the divergent discourses on social inclusion/ exclusion. Rather than simply accept a typology developed in a different context for a different purpose, both O'Sullivan (1999) and Tormey (2003) have, in broadly similar ways, sought to map out the different positions which are visible in the use of concept 'educational disadvantage'. O'Sullivan, in particular, identifies six divergent uses of the term educational disadvantage, each underpinned by a different political position. The six he identifies $(1999,12-14)$ are:

o a focus on the constitutional limitations of the person, i.e., identifying that people who are educationally disadvantaged are presumed to have a low intellectual capacity

o a focus on a presumed personal deficit in the socialisation of some pre-school children which leaves them unable to benefit fully from the education offered by school

o a focus on a presumed cultural deficit in the environment of some children, which gives rise to them developing anti-school and anti-social attitudes and values

o a focus on schooling practices which are identified as culturally irrelevant, such as the decision by schools to require particular patterns of speech or behaviour which are alien to some young people, thereby giving rise to a cultural discontinuity for them which impacts on their learning

o a focus on the material condition (wealth or poverty) of the pupil's community and on the impact this material condition has on their housing, healthcare and school conditions

o a focus on the broader political economy, which identifies that the current system of disadvantage exists because those parents who are in a position to do so try to give their children an advantage in society (through education), thereby placing others at a disadvantage.

This focus on a diversity of meanings is not to suggest that there is no agreed reference point for the concept of educational disadvantage. Across the range of political positions 
which underlie the use of the term there is an agreement that the term relates to differentials in educational outcomes. At the same time, beyond this very vague agreement, the concept is always used in a way which is embedded in a political context and with a range of political assumptions built in. This is an important point because, as O’Sullivan (2005) and Tormey (2007) have pointed out, educational disadvantage is typically not presented in this way, particularly in governmental documents which tend to present it as a term around which there is a consensus (see, for example, Ireland, 1997; 2002; 2007). Long $(2008,129)$ describes this as a result of 'noise' in educational debates which sees a collection of radically divergent views assembled under a given heading, all under the guise of achieving 'consensus'. O'Sullivan suggests a different term pastiche-making - through which traces of different understandings become merged and mixed in a manner which ignores or hides the dynamic contestation between different positions $(2005,319)$. As Gallie would point out, this denies the possibility to think critically about these different positions and ensures that "ideologically dominant educational views [are made] seem unproblematic and self-evidently true” (Carr 1998, 326).

Such structured silences are not simply definitional however. The central argument of this paper is that models of measuring educational disadvantage, and the policy targets that are related to them, are also centrally involved in obscuring the essentially political nature of educational disadvantage. It is to this that I now turn. 


\section{Measurements and targets in educational disadvantage policy}

In the 1990s the question of the measurement of educational disadvantage became increasingly important in Ireland. Questions as to the extent of the problem gave rise to a number of attempts to quantify it (e.g. Kellaghan et al. 1995; NESF 1997; the range of attempts are summarised by Boldt and Devine 1998) in order that appropriate targets for policies could be set and progress (or lack of progress) in meeting these targets could be measured. As Boldt and Devine put it:

In the Republic of Ireland, most research has not been concerned with defining the term and finding explanations for the problem. Instead, it has focused on identifying the extent of educational disadvantage, identifying factors which relate strongly to it, and proposing measures to address the perceived problem (italics added, 1998, 8).

While measurement of disadvantage was the central concern of much of the literature in the area in the 1990s, it is notable that this literature tended not to be linked to the more political debates as to the different perspectives on educational disadvantage. Put simply, people generally set out to measure the concept (and through those measures to identify ways in which targets could be set for policy) without making clear which of the competing versions of the concept they were now seeking to embed in such measures and targets. They were, in O’Sullivan's terms, engaging in the "phoney consensus" which surrounded the term educational disadvantage by treating it as a non-contested term and in doing so were sustaining the impression that such measurement was in some way a non-political, technical exercise.

Power and Tormey (2000) identify that two broad approaches to measurement of educational disadvantage were used in Ireland in the 1990s, two broad approaches that 
continued to be used in Ireland, and internationally, more recently (see UNICEF 2002 for example). The two approaches are:

o an outputs-led approach

o a comparative approach.

The outputs-led approach focuses on setting minimal standards of attainment (such as minimal levels of literacy or of attainment in state examinations) and identifying those who do not attain this level as being educationally disadvantaged. One might, for example, identify that five passes in a Leaving Certificate examination (the terminal examination in Irish post-primary schools) is a minimal requirement, in which case, those who do not attain this are identified as disadvantaged (this is the approach taken by Crooks and Stokes, [1987, 65] for example). Another, more complex, variant of this approach is to set a minimum educational standard and then identify only those who are both below this standard and poor as being disadvantaged. This is the approach used in the most comprehensive Irish attempt to measure disadvantage, the 1995 study commissioned by the Department of Education and the Combat Poverty Agency (Kellaghan et al. 1995). This model has two benefits from the viewpoint of the policy maker: first, it can be used to target (resources at) individuals, and secondly it can be used to count the number of disadvantaged people, and thereby to identify if policies are having an impact.

The comparative approach, on the other hand, identifies that if there are systematic differences in participation or attainment between different social groups then this can be taken to identify the existence of processes of disadvantaging. For instance, if a young 
person from a semiskilled or unskilled manual background is less likely to get five passes in the Leaving Certificate than one from a professional background then this can be taken to show the existence of some processes of disadvantaging. This is the sort of approach taken by Clancy (1995), by Power and Tormey (2000) and, indeed, by most sociological studies of educational disadvantage in Ireland. In this model the 'ideal' situation would be if the same proportion of working class young people got, for example, five passes in their Leaving Certificate as is the case with young people from middle class or professional backgrounds. By assessing the extent to which this is or is not the case we could measure government's success or failure in tackling disadvantage. This model does not, however, allow for an individual to be identified as 'a disadvantaged person' since the comparison is done on the basis of groups rather than on an individual basis. This is only a problem, however, if targeting individuals is seen as a necessary function of the measurement model.

Power and Tormey do not provide an analysis of the political philosophies that underlie the different approaches to measurement. Kathleen Lynch $(1999,15)$, on the other hand, does begin this process. She shows that the comparative approach to measuring educational inequality (she refers to it as the 'equality empiricist' approach) is based on the assumption that inequality is a normal part of society, and that the key question it addresses is whether or not someone has an equal chance of attaining any particular rung upon the ladder of inequality. (This vision of society is also referred to as the 'meritocratic ideal' - the idea that a person gets their educational [and monetary] reward based on their ability and their effort - and is an idea which presupposes that there should 
be greater or lesser rewards for different people [see Drudy and Lynch 1993, 60]). She suggests that comparative studies do not actually explore the extent of educational equality: rather they explore the extent to which someone has an equal opportunity within a context of structured inequality. As such, the comparative approach can be seen to be based upon a politically liberal understanding of the term 'equality', one which, she argues, is quite limited when compared to a radical understanding of 'equality' (see Baker [1998] and Lynch [1999] for a fuller account of basic, liberal and radical perspectives on equality).

Lynch's contribution to the debate is important given that it clearly exposes the way in which measurement ultimately embodies a political perspective. However, her focus on deconstructing the politics that underlies comparative models adds little to our understanding, because, as we will see below, the model of measurement and targetsetting that was embedded in the NAPS educational policy and in subsequent statements was not the 'comparative model', but rather the 'outputs-led' model. It is the political position embedded in this model that we need, therefore, to excavate. In fact, using this outputs-led approach to measurement has at least four corollaries, all of which are distinctly political.

First, the model assumes that the test used to determine a successful educational outcome is, in itself, a meaningful measure. As Lyons (2002) and Mac Ruairc (2009) have identified, standardised tests can have an in-built bias and can fail to adequately enable some pupils (those who are not from powerful groups in society) to reflect their 
capabilities. Mac Ruairc ties this focus on measurement to a broader 'managerialist' ideology within education systems, which Apple (2001) has argued is part of a broad alliance of conservative and neo-liberal political perspectives on education. (It is worth noting that this criticism can be directed at both outputs-led and comparative models, since both rely on some measure of educational attainment.)

Second, the model is based on identifying individuals as being disadvantaged and is linked to the desire to target individuals or areas for intervention (Power and Tormey 2000). As O’Sullivan (1999) has pointed out, such targeting is generally predicated on the belief that it is the person, their school or community which needs to be changed, not the broader education or economic system. Indeed, in a context where disadvantage is predominantly rural, and significant bodies of Irish research identify that such targeting is unlikely to be effective in addressing disadvantage (Kellaghan et al. 1995, 71; Pringle 1999, 271), the choice to use a measure that reinforces the targeting concept can be seen to have distinctly conservative political undertones (i.e., focussed on protecting the status quo).

Third, by setting a minimum standard for measuring disadvantage, this measure ignores the extent to which educational qualifications are used competitively in the jobs market. Put simply, if the measure identifies that the goal is to get everyone to a Leaving Certificate, it leaves open the possibility of middle class parents, or other comparatively privileged groups, continuing to ensure the comparative advantage of their children by either investing in higher education, or by using alternative mechanisms such as social 
networks. Indeed, Layte and Whelan (2000, 104 -107) have suggested that Irish data does in fact indicate that, as educational qualifications such as the Leaving Certificate become more widespread, alternative means of ensuring advantage for middle class children become more evident. Put simply, the outputs-led model ignores the extent to which the existence of 'advantage' necessarily implies 'disadvantage' (Derman-Sparks 2002, 59). In this, it operates from a distinctly consensualist perspective (Drudy and Lynch 1993, 50) which fails recognise or to challenge unequal economic and power relations in society. This too reveals its essentially politically conservative undertones.

Fourth, the outputs-led model pays no attention to the experience of those who score above the minimum standard specified. What this means in practice can be seen by imagining a situation in which someone with a strong aptitude for science gets a five passes in her Leaving Certificate, but, because of the processes of disadvantaging which have operated in her life, does not get sufficient points, or does not have sufficient resources, to enable her to access or take up a third-level course in science, and who, subsequently, never fulfils her personal capacity, never reaches her earning capacity nor makes the contribution to society which she could potentially have made. Under the outputs-led model, such a person would not be identified as disadvantaged. By more liberal standards, one could note that her education has not been sufficient to say that it was "directed to the full development of [her] personality" (the standard which is set by the UN Universal Declaration of Human Rights [United Nations 1998, Article 26\{2\}]). Certainly, for those who see education as "a significant vehicle for cultural development aimed at developing legitimate democratic representation and critical perspectives on the 
status quo” (O’Brien and Ó Fathaigh 2005, 73; see also Murphy 2005 and 2008), it falls far short. By the standards of liberal or radical equality, such a person would be identified as disadvantaged, but not by the standards set in the outputs-led model of measurement. Once more, the politically conservative agenda that is embedded in the outputs-led model is revealed.

In summary, the targets which the outputs-led model sets for the educational system are those of an conservative political perspective: one which focuses attention on the disadvantaged person while directing attention away from the possibility that processes of disadvantaging may be built into the educational system and one which identifies that it is willing to work towards increased attainment for working class children so long as this does not impact on the capacity of middle class parents to pass on wealth and power to their children. What is most striking, however, is that the proponents of the outputsled model do not make clear the political overtones of their approach. Measurement is presented as if it is a technical matter, a function of statistical know-how and access to an appropriate database. In this way, the encroachment of conservative politics into educational disadvantage policy is achieved silently, and without debate. This can be seen in the targets set in the National Anti-poverty Strategy, and thereafter.

\section{The targets for educational disadvantage policies set in the NAPS}

In 1997, the Government of the day (the 'Rainbow Coalition’ of Fine Gael, Labour and Democratic Left) launched the National Anti-poverty Strategy (NAPS) that was aimed at ensuring that the social and economic changes then underway in Ireland gave rise to 
reduced social inequalities and polarization (Ireland 1997, 2). A number of key areas were identified as being central to achieving this aim, the first of which was educational disadvantage (the others were, in order of listing, unemployment, particularly long-term unemployment, income adequacy, disadvantaged urban areas and rural poverty [1997, 8 9]). The NAPS adopted a relative or comparative measure of poverty (in other words, it did not set a minimum standard of income, but rather focused on inequalities in resources between different people and social groups). Indeed, the strategy made the reduction of inequalities one of its key principles (1997, 3 and 7). Arguably, this comparative focus and targets reflected the social democratic politics of the constituent parties of the government.

For some reason, however, this political agenda of the Strategy did not lead to the use of comparative measures of educational disadvantage in setting targets for the strategy. Instead, an output-led model was used, with 'early school leaving' being designated as the key measure of educational disadvantage. The strategy outlined that it aimed:

... to eliminate the problem of early school leaving before the junior certificate, and reduce early school leaving such that the percentage of those completing senior cycle will increase to at least $90 \%$ by the year 2000 and $98 \%$ by the year 2007...(1997, 9).

It is worth noting that the targets set by the strategy were, in many respects ambitious. It seems likely that the ambition of the strategy far exceeded that of the Department of Education and Science, insofar as it is generally clear that nowhere near enough was done in subsequent years to ever hope to achieve these targets. At the same time, it is also clear that, whatever their ambition, the target chosen embedded a conservative political 
measure of disadvantage in the heart of the anti-poverty educational policy process. Somewhere in the transition from principle to targets, the apparently value-free device of measurement spirited a deeply conservative political agenda into what was designed as, essentially, a flagship for social democratic politics in Ireland.

The story does not end there. The National Anti-poverty Strategy was reviewed under the watch of the Fianna Fáil/ Progressive Democrat coalition that replaced the Rainbow Coalition soon after the original strategy was launched (Ireland 2002). This review gave rise to a new iteration of the Strategy, with a range of new targets, including new targets in the area of educational disadvantage. Although the public consultations that gave rise to this review drew attention to the problems of measurement that were implicit in the original strategy, and although it was verbally suggested by at least one eminent educational researcher at these public consultations that there was now a need to move to comparative targets, the revised targets did not move from outputs-led to comparative measures. Instead, sights were lowered to match limited ambition, and the targets of $90 \%$ school completion in senior cycle in 2000 (a target that had already been missed) and $98 \%$ in 2007 were simply lowered to the new targets of $85 \%$ school completion in 2003 and 90\% in 2006 (Ireland 2002, 12). Indeed, this process continues to be evident today, with at least some of the targets set for the National Action Plan for Social Inclusion 2007 - 2016 (Ireland 2007) being little more than re-heated versions of previous output measures: this plan indicates that as one of its goals, it will: "Work to ensure that the proportion of the population aged 20-24 completing upper second-level education or equivalent will exceed 90 per cent by 2013” (2007, 33). 
Although the NAPS has now been supplanted by a rolling series of new initiatives that create the impression of much activity in the field, many of the processes that were seen in the strategy are still evident in educational policies and broader social inclusion policies today. Although more recent documents utilise the language of the political liberal (such as in the discussion of a rights-based approach, for example), the targeting of individuals remains a key factor in the measurement of educational disadvantage (Educational Disadvantage Committee 2004, 1-9) and alternative approaches to measurement are still ignored (2004, 3-4). As such, educational disadvantage policy is probably best characterised as something of a muddle. While broad statements of principle point in one political direction there appears to be no realisation that at the same time, the models of measurement and the policy targets set allow the 'expert' to silently, and without debate or contestation, point policy in a different, conservative, direction.

\section{Conclusion}

Carr (1998) notes that debates on education often have embedded within them ‘ideological’ perspectives which remain unarticulated, but which, nonetheless are crucial to understanding the debates. Similarly, O’Sullivan (1999; 2005) identifies that many discussions on educational disadvantage operate on the basis of a phoney consensus or pastiche: the contestation of perspectives underlying the discussion is never overtly revealed, and, as such, the capacity to use this diversity of perspectives as an opportunity for critical thinking is denied. This is all the more surprising given that contestation is a key element of almost all the academic literature on educational disadvantage in Ireland 
and internationally.

The implications of this phoney consensus in policy debates can be seen in relation to the literature on measures and targets for educational disadvantage policy in Ireland. Although the issue of identifying targets is clearly a part of a broader political debate about the nature of the society in which we wish to live, this broader issue is not made explicit in this literature. While broader conceptualisations seem to draw on notions of relative poverty and human rights, these notions are not followed though into the setting of measures and targets for policy. Measures and targets, like definition, are largely treated as a technical or value-free issue. The implications of this can be seen starkly in the NAPS, and in the documents, strategies and plans that followed it.

\section{References}

Apple, M. 2001. Educating the 'right' way: markets, standards, God and inequality. London: RoutledgeFalmer.

Baker, J. 1998. Equality. In Social Policy in Ireland, Principles, Practices and Problems, ed. S. Healy and B. Reynolds. Dublin: Oak Tree Press.

Boldt, S. and B. Devine 1998. Educational Disadvantage in Ireland: Literature Review and Summary Report. In Educational Disadvantage and Early School Leaving, ed. Doyle, P. Dublin: Combat Poverty Agency.

Bourdieu, P. and J-C. Passeron 1977. Reproduction in Education, Culture and Society. London: Sage.

Carr, W. 1998. The Curriculum in and for a Democratic Society. Curriculum Studies 6. Vol. 3: 323-340.

Clancy, P. 1995. Access to College: Patterns of Continuity and Change. Dublin: Higher Education Authority.

Conway, P.F. 2002. Learning in Communities of Practice: rethinking teaching and learning in disadvantaged contexts. Irish Educational Studies 21, No. 3: 61-91.

Cox, T. 2000. Combating Educational Disadvantage: Meeting the Needs of Vulnerable Children. London: Falmer Press.

Crooks, T. and D. Stokes, ed. 1987. Disadvantage, Learning and Young People: The Implications for Education and Training. Dublin: CDVEC CDU, TCD.

Derman-Sparks, L. 2002. Disadvantage and Diversity: Untangling Their Roles In Children's Development and in Education. In Primary Education: Ending 
Disadvantage; Proceedings and Action Plan of the National Forum, ed. St. Patrick’s College, Drumcondra. Dublin: St. Patrick’s College, Drumcondra.

Drudy, S. and K. Lynch 1993. Schools and Society in Ireland. Dublin: Gill and Macmillan.

Educational Disadvantage Committee 2004. Submissions Made to the Minister for Education and Science 2003 Report. Dublin: Educational Disadvantage Committee.

Educational Disadvantage Committee 2005. Moving Beyond Educational Disadvantage; Report of the Educational Disadvantage Committee 2002 -2005. Dublin: Educational Disadvantage Committee.

Gallie, W.B. 19955/6. Essentially Contested Concepts. Proceedings of the Aristotelian Society 56:167-198.

INTO 1994. Poverty and Educational Disadvantage, Breaking the Cycle. Dublin: Irish National Teachers Organisation.

Ireland 1997. National Anti-poverty Strategy. Dublin: Stationery Office.

Ireland 2002. Building an Inclusive Society. Dublin: Stationery Office (also, web site: http://www.welfare.ie/publications/naps/bais.pdf, Accessed 28 October 2004).

Ireland 2007. National Action Plan for Social Inclusion 2007 - 2016. Dublin: Stationery Office.

James, E.A. 2005. Prospects for the Future: the use of participatory action research to study educational disadvantage. Irish Educational Studies 24, No. 2: 119-206.

Joseph Rowntree Charitable Trust 2007. Experiences of Poverty and Educational Disadvantage York: Joseph Rowntree Charitable Trust.

Kellaghan, T. 2001. Towards a Definition of Educational Disadvantage. The Irish Journal of Education xxxii: 3-22.

Kellaghan, T., S. Weir, S. Ó hUallacháin and M. Morgan 1995. Educational Disadvantage in Ireland. Dublin: Education Research Centre, Combat Poverty Agency and Department of Education.

Layte, R. and C.T. Whelan 2000. The rising tide of equality of opportunity: the changing class structure. In Bust to Boom? The Irish Experience of Growth and Inequality, ed. B. Nolan, P.J. O’Connell and C.T. Whelan. Dublin: Institute of Public Administration.

Levitas, R. 2005. The Inclusive Society? Social Exclusion and New Labour. Hampshire: Palgrave Macmillan.

Long, F. 2008. Protocols of Silence in Educational Discourse. Irish Educational Studies 27, No. 2: 121-132.

Lynch, K. 1999. Equality in Education. Dublin: Gill and Macmillan.

Lyons, C.W. 2002 Conceptions of Intelligence and Educational Disadvantage. Irish Educational Studies 21, No. 1: 1 - 18.

Murphy, T. 2005. Maxine Greene and the democratic project in education: signposts for the Irish educational system. Irish Educational Studies 24, No. 1: 55-64.

Murphy, T. 2008. Democratic schooling Practices in the Republic of Ireland: the gaps between the rhetoric and reality. Irish Educational Studies 27, No. 1: 29-39.

NESF 1997. Early School-leavers and Youth Unemployment, Forum Report No. 11. Dublin: National Economic and Social Forum. 
OECD (Organisation for Economic Cooperation and Development) 1992. High Quality Education and Training for All. Paris: OECD.

O’Brien, S. and M. Ó Fathaigh 2005. Bringing in Bourdieu's theory of social capital: renewing learning partnership approaches to social inclusion. Irish Educational Studies 24, No. 1: 65-76.

O’Sullivan, D. 1999. Educational Disadvantage: Excavating Theoretical Frameworks. In Strategies to Address Educational Disadvantage, ed. K. Fahy. Galway: Community Workers Co-operative.

O’Sullivan, D. 2005. Cultural Politics and Irish Education since the 1950s. Dublin: Institute of Public Administration.

Power, C. and R. Tormey 2000. Refocusing the Debate: An Examination of the Interplay between Measurement and Intervention in Educational Disadvantage. CEDR Occasional Paper No 2. Limerick: Centre for Educational Disadvantage Research.

Pringle, D. 1999. Something Old, Something New: Lessons to be Learned from Previous Strategies of Positive Territorial Discrimination. In Poor People, Poor Places, A Geography of Poverty and Deprivation in Ireland, ed. D. G. Pringle, J. Walsh and M. Hennessy. Dublin: Oak Tree Press and Geographical Society of Ireland.

Sugrue, C. and J. Gleeson 2004. Signposts and Silences: Situating the Local within the Global. In Curriculum and Ideology, Irish Experiences, International Perspectives, ed. C. Sugrue. Dublin: The Liffey Press.

Tormey, R. 1999. Disadvantage or Disadvantaging - Conceptualising Class Difference in Education as a Disease or as a Process? Irish Journal of Applied Social Studies 2, No. 1: $27-50$.

Tormey, R. 2003. Introduction: Initial Teacher Education and Socio-economic Inequality. In Time For Action: Re-shaping Initial Teacher Education to Meet the Challenge of Socio-economic Inequalities in Education, ed. R. Tormey. Limerick: Centre for Educational Disadvantage Research.

Tormey, R. 2007. Education and Poverty. In Welfare Policy and Poverty, ed. M. Cousins. Dublin: Institute of Public Administration.

United Nations 1998. All Human Rights for All: the Fiftieth Anniversary of the Universal Declaration of Human Rights, 1948-1998. United Nations. http://www.un.org/Overview/rights.html.

UNICEF (United Nations Children's Fund) 2002. A League Table of Educational Disadvantage in Rich Nations; Innocenti Report Card, Issue No. 4. Florence, Italy: UNICEF Innocenti Research Centre.

Weber, M. 1922/ 1978. Economy and Society. Berkley: University of California Press.

Weir, S. and P. Archer 2005. A Review of Procedures to Select Schools for Support to Deal with Educational Disadvantage. The Irish Journal of Education xxxvi: 6385. 